p-ISSN 1693-9484, $e$-ISSN : 2621-8313

Majalah Ilmiah Bahari Jogja (MIBJ)

Vol. 19 No. 1, Februari $2021 \quad(25-39)$

DOI: $0.33489 /$ mibj.v19i1.256

(C) 2021 Sekolah Tinggi Maritim Yogyakarta

\title{
QUALITY PROGRAM LIFE CYCLE SEBAGAI MODEL DIKLAT PENGEMBANGAN PEMBERDAYAAN MASYARAKAT BERBASIS RISET
}

\author{
Romanda Annas Amrullah'*, Budi Joko Raharjo², Yovananda Bayudewa \\ Kusumawardhana ${ }^{3}$ \\ ${ }^{1,2,3}$ Politeknik Ilmu Pelayaran Semarang,Jl. Singosari Raya No.2A, Wonodri, Kec. \\ Semarang Sel., Kota Semarang, Jawa Tengah 50242 \\ *Corresponding Author. E-mail: romanda@ pip-semarang.ac.id. HP:08122572392
}

\begin{abstract}
Abstrak
Pendidikan dan pelatihan kejuruan (vokasi) berbasis kompetensi keahlian memainkan peran kunci dalam mempromosikan daya saing dan kemakmuran ekonomi. Namun, di Indonesia sebagai negara yang memiliki bonus demografi dan negara maritim belum menjadi prioritas untuk mengembangkan sumber daya manusia yang tangguh untuk mengelola kekayaan wilayah laut hal ini tercermin dalam kurikulum vokasi yang tidak pernah direkontruksi mengikuti perubahan lingkungan eksternal. Jenis penelitian ini adalah journal research dengan methode kualitatif ekplanasi. Mengintegrasikan teori konsep model kuwalitas pendidikan dan pelatihan Finlandia, teori pilihan siswa untuk menentukan pilihan perguruan tinggi serta teori konsep model pendidikan dan latihan siklus hidup maritim dari Eropa. Penelitian menghasilkan konsep model kebaharuan Quality Program Life Cycle. Quality Program Life Cycle adalah model pendidikan vokasi yang mengutamakan kualitas (perekrutan, pendidikan, pelatihan dan pendampingan) secara berkualitas (taruna, dosen, karyawan/staff, pelatihan) dengan program yang terukur, tansparan dan akuntabilitas dengan keterlibatan penuh institusi/lembaga, mahasiswa dan perusahaan sebagai perputaran (Life Cycle) secara berkelanjutan. Penjelasan dimensi, konsep, operasional dijelaskan lebih lanjut dalam penelitian ini.
\end{abstract}

Kata kunci: vokasi, pendidikan dan pelatihan, pilihan mahasiswa, Quality Program Life Cycle, transparan dan akuntabel

\begin{abstract}
Skill-based vocational education and traning play a key role in promoting competitiveness and economic prosperity. However, in Indonesia as a country that has a demographic dividend and a maritime country has not become a priority for developing strong human resources to manage the wealth of the marine area, this is reflected in the vocational curiiculum that has never been reconstructed following changes int the external environment. This type of research is a hournal research with a qualitative explanation method. Intergrate finnish education and traning quality model conceptual theory, student choice theory to determine higher education choice and European maritime life cycle education and training model concept theory. The research resulted in the concept of a novelty model of the Quality Program Life Cycle Quality Program
\end{abstract}


Life Cycle is a vocational education model tha prioritizes quality (recruitment, educatiob, training and mentoring) in a quality manner (cadets, lecturers, employees / staff, training) with a program that is measurable, transparent and accountable with full involvement of institutions, students and companies as a cycle (Life Cycle) in a sustainable manner. The explanation of dimensions, conceots, operations is further explained in this study.

Keywords: vocational, education and traning, student choice, Quality Program Life Cycle, transparent and accountable

\section{PENDAHULUAN}

Pemberdayaan wilayah pesisir (maritim) menjadi skala prioritas pemerintah untuk kemakmuran bangsa. Hal ini merupakan konsekuensi logis sebab wilayah Indonesia merupakan negara kepulauan, berdasarkan informasi Kementerian Dalam Negeri Tahun 2018 yang dipublikasikan dalam Buku Statistik Indonesia 2018, Indonesia memiliki 16.056 pulau pada 2017. Namun, Jumlah ini berkurang 1.448 pulau dari sebelumnya sebanyak 17.504 pulau (Badan Pusat Statistik, 2019). Berkurangnya pulau yang dimiliki oleh indonesia disebabkan oleh beberapa hal, lepasnya Pulau Sipadan-Ligitan ke malaysia (Juwana, 2003). Lepasnya kedua pulau dari Indonesia merupakan permasalahan yang disebabkan oleh beberapa hal, Pertama, aspek keamanan yang berkaitan dengan aspek perlindungan dan pemeliharaan. Kedua, banyak di antara pulau-pulau tersebut yang tidak berpenghuni. Ketiga, aspek pemberdayaan masyarakat (Alihar, 2018). Pemerintah dalam hal ini presiden mengeluarkan Peraturan Presiden (Perpres) Nomer 16/2017 tentang Kebijakan Kelautan Indonesia telah ditanda-tangani oleh presiden pada tanggal 20 Februari 2017. Perpres ini merupakan salah satu implementasi janji pemerintahan Presiden Joko Widodo-Jusuf Kalla untuk menjadikan Indonesia sebagai poros maritim dunia.

Pemberdayaan masyarakat yang berada di wilayah pesisir memiliki keunggulan, menjaga budaya masyarakat maritim (Adi, 2018), Pengelolaan Sumber Daya Laut Tradisional (Adhuri, 2018), pemberdayaan masyarakat maritim untuk pertahanan negara (Defence, 2015), dan sampai pada pertahanan ekonomi, Pemberdayaan ekonomi adalah upaya untuk meningkatkan kemampuan masyarakat untuk memenuhi kebutuhan mereka dan memiliki kesejahteraan, dapat mempengaruhi peningkatan pertahanan nasional (Nugraha, 2018). Namun, pemberdayaan masyarakat maritim tidak semudah yang dibayangkan oleh pemerintah dalam membuat kebijakan, kegagalan pemberdayaan masyarakat maritim disebabkan oleh rendahnya partisipasi masyarakat (Wahid et al., 2017), tidak sesuai program pemberdayaan dengan kebutuhan kerja (Binat Sarwar \& Hunt, 2017), pendekatan yang salah terhadap masyarakat (Morton \& Montgomery, 2010), kuwalitas program pemberdayaan masyarakat yang rendah (Soedarto, 2017) hal ini karena tidak adanya siklus hidup keberlanjutan antara pemerintah, masyarakat, lembaga dan dunia kerja.

Pengembangan pendidikan dan pelatihan masyarakat didasarkan pada antisipasi kuantitatif permintaan jangka panjang untuk tenaga kerja dan kebutuhan 
pendidikan dan antisipasi kualitatif kebutuhan keterampilan di tingkat nasional (Pilz, 2012). Upaya antisipasi menghasilkan informasi tentang jenis keterampilan dan orang-orang terampil yang dibutuhkan di dunia kerja masa depan dan caracara di mana permintaan ini dapat dipenuhi melalui pendidikan dan pelatihan. Tujuannya adalah untuk mencocokkan permintaan kuantitatif dan penawaran tenaga kerja sedekat mungkin. Selain itu, data antisipasi dapat digunakan untuk mengembangkan kerangka kerja kualifikasi, persyaratan keterampilan kejuruan (Kurikulum Inti Nasional untuk Kualifikasi Kejuruan Menengah Atas dan Persyaratan Kualifikasi Berbasis Kompetensi) dan instruksi untuk lebih memenuhi kebutuhan keterampilan dunia kerja di masa depan. Pendidikan dan pelatihan kejuruan sangat banyak didasarkan pada sistem kualifikasi berbasis kompetensi. Manfaat spesifik dari sistem ini adalah memungkinkan untuk mengenali kompetensi kejuruan seseorang terlepas dari apakah kompetensi tersebut diperoleh melalui pengalaman kerja, studi, atau aktivitas lainnya. Namun, pendidikan dan pelatihan memerlukan biaya mahal untuk mendapatkan serifikasi kompetensi yang diinginkan masyarakat, penetapan harga yang lebih rendah dan kualitas yang lebih tinggi hampir tidak terjadi bersamaan dalam bisnis apa pun dan perguruan tinggi bidang maritim tidak terkecuali. Sementara ada persepsi umum di masyarakat bahwa industri pelayaran dan maritim memberikan peluang kerja yang sangat menggiurkan untuk menarik siswa ke pendidikan pasca sekolah menengah telah terbukti menjadi tantangan. Sekretaris Jenderal IMO Koji Sekimizu mengatakan dalam pesan Hari Maritim Dunia 2015 bahwa upaya yang lebih besar harus dilakukan untuk membawa generasi baru ke bidang maritim sebagai sebuah profesi [6]. Bekerja dan berkarier di bidang maritim dituntut untuk berdisiplin tinggi dan memiliki keahlian sebab berkaitan dengan resiko tinggi. Masyarakat tidak mampu memerlukan pelatihan untuk mendapatkan sertifikasi kompetensi dari perguruan tinggi yang memiliki kompetensi dibidang maritim, kualitas baik, program yang mampu menjawab tantangan dunia kerja dan diakui oleh pemerintah dan dunia internasional dalam hal ini International Marine Organizations (IMO).

Penelitian ini menguraikan konteks pelatihan pemberdayaan masyarakat kelautan di Indonesia, menyoroti ketidakcocokan saat ini antara kebutuhan kebijakan dan industri di dunia yang berubah, fungsi pengabdian masyarakat bagi dosen dan perguruan tinggi, pemetaan yang lebih rinci dari pemberdayaan masyarakat, mengeksplorasi kekuatan dan kelemahannya saat ini untuk mengidentifikasi kesenjangan dan kebutuhan utama yang harus diatasi. Tantangan dan peluang ini kemudian dibahas dalam konteks konsep kebaharuan "Quality Program Life Cycle", yang mengusulkan pendekatan untuk mengembangkan, memperluas, dan memodernisasi skema saat ini, dengan contoh-contoh yang relevan.

\section{Rumusan Masalah}

Pendidikan dan latihan pemberdayaan masyarakat merupakan rutinitas dihadapi oleh lembaga pendidikan perguruan tinggi sebagai salah satu tugas pokok menjalankan tri dharma perguruan tinggi yaitu pengabdian kepada masyarakat namun, hingga sekarang konsep model untuk melakukan pendidikan dan latihan belum dikaji secara akademis manfaat dan kelemahan dari yang sudah

Majalah Ilmiah Bahari Jogja 27 | http://jurnal.amy.ac.id/index.php/MIBJ/ 
dijalankan, baik secara kwalitas, program dan peran pihak - pihak yang terlibat didalamnya, maka proposal penelitian ini merumuskan beberapa permasalahan sebagai berikut;

1. Bagaimanakah kuwalitas antara pendidikan dan latihan yang dijalankan terhadap kebutuhan dunia kerja?

2. Apakah program yang dilaksanakan dalam pendidikan dan latihan telah sesuai dengan kebutuhan dunia kerja?

3. Bagaimanakah peran masing - masing institusi terkait terhadap pendidikan dan latihan pemberdayaan masyarakat?

4. Apakah konsep model "Quality Program Life Cycle", mampu menjawab permasalahan yang ada terhadap kebutuhan kerja?

\section{Tujuan Penelitian}

Visi presiden untuk menjadikan Indonesia sebagai poros maritim dunia diterjemahkan melalui Peraturan Presiden (Perpres) Nomor 16/2017 tentang Kebijakan Kelautan Indonesia, dengan luas daratan hanya $1.913 .578,68 \mathrm{~km}^{2}$, jauh dari luas lautan yang dimiliki oleh Indonesia yaitu $6.292 .156,82 \mathrm{~km}^{2}$, jumlah pulau mencapai 14.572 yang sudah memiliki nama dan berkordinat. Namun, luasnya wilayah laut yang dimilik belum digali maksimal potensi sumber daya laut karena keterbatasan sumber daya manusia yang dimiliki, belum memiliki konsep yang tepat untuk memberdayakan masyarakat wilayah pesisir, keterbatasan keahlian yang dimiliki oleh masyarakat untuk mengelola potensi kelautan, kebijakan yang tidak sinkron dengan kebutuhan masyarakat dan adanya missmatch pelatihan yang ada dengan kebutuhan di lapangan. Maka, tujuan penelitian ini adalah sebagai berikut:

a. Untuk meningkatkan kwalitas pendidikan dan pelatihan dibidang kelautan.

b. Untuk meningkatkan program pendidikan dan latihan keahlian masyarakat wilayah pesisir.

c. Untuk mengimplementasikan konsep kebaharuan "Quality Program Life Cycle" sebagai model pemberdayaan masyarakat pesisir.

d. Untuk memberikan saran kebijakan yang diambil oleh pemerintah.

e. Untuk memecahkan permasalahan pola pendidikan dan pelatihan sehingga tidak terjadi missmatch pelatihan yang ada dengan kebutuhan di lapangan

\section{Kontribusi Penelitian}

Kontribusi akademis penelitian ini adalah menambah refrensi teoritis akademis dalam bidang kelautan, pemberdayaan masyarakat dan konsep kebabaharuan dalam pemberdayaan masyarakat bidang marine/ kelautan sedangkan kontribusi non akademis/praktis adalah konsep model ini dapat diterapkan pada lain bidang bagi yang memerlukan model pemberdayaan untuk mengembangkan potensi daerah yang ada.

Luaran penelitian ini sebagai bahan pertimbangan oleh pemerintah sebagai pengambil kebijakan khususnya yang berkaitan dengan pemerdayaan masyarakat khusunyan yang berkaitan dengan kelautan, luaran penelitian ini juga diseminarkan di seminar Nasional terindex sinta atau Internasional dan dijurnalkan pada terindek sinta 4 atau Internasional. 


\section{KAJIAN LITERATUR}

\section{Prinsip EUA}

Principles European University Association (Prinsip EUA) adalah prinsip berbagai kebijakan yang dikembangkan oleh Negara-negara Anggota dengan Komisi Eropa, yang melibatkan pemangku kepentingan utama berada di bawah Prinsip Pelatihan Doktor Inovatif (mengikuti dari Prinsip-prinsip EUA Salzburg (EUA, 2005). Prindip EUA merupakan konsep yang telah teruji di wilayah Eropa untuk pendidikan dan pelatihan khusus bagi mereka yang tertarik dan mendalami dunia maritim, terkonsep dengan baik mulai dari tingkat pra vokasi sampai pada tingkat tertinggi yaitu doktor dalam bidang maritim. Peneliti memasukan teori prinsip EUA sebagai bahan benchmarking dari model penelitian dan pelatihan kelautan ke pendidikan dan pelatihan karena keberhasilanya Eropa dalam menerapkan konsep tersebut dalam Ekonomi Biru. Prinsip-prinsip EUA Salzburg terdiri atas Keunggulan Penelitian, Lingkungan Kelembagaan yang Menarik, Paparan terhadap industri dan pengusaha terkait lainnya, Jaringan Internasional, Opsi Penelitian Interdisipliner, Pelatihan Keterampilan yang dapat ditransfer, Jaminan Kualitas (Vincx et al., 2018). Bidang-bidang utama untuk kemajuan pelatihan diidentifikasi dengan menganalisis tujuh Prinsip Innovative Doctoral Training dalam konteks disiplin ilmu kelautan.

Keunggulan Penelitian, penelitian menjadi menjadilangkah utama yang harus ditempuh untuk mengembangkan suatu potensi kelautan. Sebagian besar dari rekomendasi yang terkandung dalam Laporan Keadaan Pesisir ini, bergantung pada dua kualitas yang saling terkait dan mendasar (Francis et al., 2015). Pertama, seorang pimpinan, pembuat keputusan dan kebijakan serta berbagai pengguna akhir memiliki akses ke produk penelitian ilmiah untuk mengatur dan mengelola penggunaan dan eksploitasi sumber daya secara bijak. Dalam konteks ini, data, informasi, dan pengetahuan adalah dasar untuk mewujudkan manfaat Ekonomi Kelautan. Kedua, manajemen sumber daya dan basis pengetahuan yang mendasari bergantung pada ketersediaan orang dengan kemampuan yang tepat untuk menjadi pemelihara sumber daya yang bertanggung jawab tersebut. Dengan demikian, pendidikan, kesadaran dan pelatihan menawarkan solusi jangka panjang untuk pembangunan berkelanjutan ekonomi pesisir dan laut.

Lingkungan Kelembagaan yang Menarik, kelembagaan merupakan tempat dimana mahasiswa menuntut ilmu, berpikir dan menerapkan ide nya untuk menghasilkan suatu karya, apabila lingkungan kelembagaan yang tidak menarik maka potensi kreatif dari mahasiswa akan hilang. Lingkungan kelembagaan yang menarik menjadi tuntutan utuma oleh seluruh penghuni yang menempati semuatu tempat (Mechael, 2007).

Paparan terhadap industri dan pengusaha terkait lainnya, Istilah 'industri' digunakan dalam arti luas, termasuk semua tempat kerja di masa depan, dari industri ke bisnis, pemerintah, LSM, lembaga amal dan budaya (mis. Museum) (Vincx et al., 2018). Hal Ini penting dalam konteks pemberdayaan masyarakat pesisir mengingat berbagai sektor ketenagakerjaan yang dicakup. Paparan (Eksposur) dapat mencakup penempatan selama pelatihan penelitian; dana 
bersama; keterlibatan non-akademisi dari industri terkait dalam menginformasikan / menyampaikan pengajaran dan pengawasan; mempromosikan kontribusi keuangan dari industri terkait untuk program Doktor; membina jaringan alumni yang dapat mendukung kandidat (mis. skema pendampingan) dan program; dan beragam kegiatan transfer orang / teknologi / pengetahuan (Sabic \& Kemmerling, 2011).

Jaringan Internasional, Pelatihan harus memberikan peluang bagi jejaring internasional, yaitu melalui penelitian kolaboratif, gelar ganda dan bersama. Mobilitas harus didorong, baik melalui konferensi, kunjungan penelitian singkat dan penugasan, atau tinggal lebih lama di luar negeri (Vincx et al. 2018:Herdiana 2013). Jaringan internasional dalam pendidikan dan pelatihan penting dalam kelautan sebab merujuk pada aturan International Marine Organization. Semua konpetensi keahlian harus berdasarkan IMO baik yang diadakan pemerintah maupun oleh swasta.

Opsi Penelitian Interdisipliner,dalam bidang kelautan dilakukan oleh perguruan tinggi yang melibatkan masyarakat wilayah pesisir dan dunia kerja. Tujuannya adalah hasil penelitian tidak terjadi missmatch antara perguruan tinggi, pemerintah dan dunia kerja. Penelitian dan pelatihan itu sendiri lintas disiplin. Ini berarti bahwa pelatihan kelautan harus tertanam dalam lingkungan dan budaya penelitian terbuka untuk memastikan bahwa setiap peluang yang tepat untuk pemupukan silang antar disiplin ilmu dapat menumbuhkan pendekatan luas dan interdisipliner yang diperlukan(Vincx et al., 2018).

Pelatihan Keterampilan yang dapat ditransfer, Menurut European Science Foundation: "Keterampilan yang dapat ditransfer adalah keterampilan yang dipelajari dalam satu konteks (mis. Penelitian) yang berguna dalam konteks lain (mis. Pekerjaan di masa depan baik itu dalam penelitian, bisnis, dll.). Mereka memungkinkan keterampilan yang terkait dengan subjek dan penelitian untuk diterapkan dan dikembangkan secara efektif. Keterampilan yang dapat ditransfer dapat diperoleh melalui pelatihan atau melalui pengalaman kerja "(European Science Foundation 2010). Sangat penting untuk memastikan bahwa cukup banyak peneliti memiliki keterampilan yang dituntut oleh ekonomi berbasis pengetahuan (Vincx et al. 2018; Mechael 2007; Sabic and Kemmerling 2011).

Jaminan Kualitas, Prosedur pertanggungjawaban harus ditetapkan atas dasar penelitian pendidikan dan harus dikembangkan secara terpisah dari penjaminan kualitas dalam siklus pendidikan pertama dan kedua (Vincx et al., 2018). Tujuan dari penjaminan kualitas adalah untuk meningkatkan kualitas lingkungan penelitian serta mempromosikan prosedur yang transparan dan bertanggung jawab untuk topik-topik seperti penerimaan, pengawasan dan pengembangan karir. Penting untuk ditekankan bahwa ini bukan hanya tentang jaminan kualitas itu sendiri, tetapi juga proses atau siklus hidup dari rekrutmen hingga kelulusan. Ini berarti bahwa pengembangan karir melampaui kelulusan kandidat laut dimulai dari rekrutmen (Shury et al., 2017). Kebutuhan pelatihan mereka dinilai pada saat kedatangan dan Rencana Pengembangan Karir Pribadi (PCDP) disiapkan (Ohlsson \& Borg, 2010). Ini berisi rincian program yang akan mereka ikuti dan berbagai penempatan di industri dan di laut, misalnya. Ini harus dipantau dan terus diperbarui. 


\section{Program Kampus Pilihan}

Program kampus pilihan merupakan serangkaian program yang dimiliki oleh kampus (perguruan tinggi) sebagai jawaban dan antisipasi yang dibutuhkan oleh dunia kerja. Bentuk ini dapat berupa pendidikan dan latihan atau program reguler sistem sks. Keputusan seorang calon taruna untuk memperoleh pengetahuan lanjutan adalah puncak dari proses penimbangan biaya terhadap manfaat sebab meningkatnya permintaan masyarakat untuk masuk dalam pendidikan tinggi yang terkenal (namun belum tentu berkwalitas bagus) menyebabkan pasar pendidikan tinggi menjadi kompetitif dan monopolistis (Labas et al., 2018). dan ini mirip dengan proses yang diterapkan ketika pelanggan memilih suatu produk atau layanan (Stankevich, 2017). Pilihan calon taruna untuk masuk perguruan tinggi didasarkan pada interaksi antara karakteristik calon taruna dari status sosial ekonomi, bakat, aspirasi dan prestasi pendidikan dan serangkaian pengaruh eksternal. Pertumbuhan yang tinggi dan meningkatnya permintaan juga mengintensifkan kompetisi di dalam lembaga pendidikan tinggi 'untuk menarik lebih banyak perhatian calon taruna (Edirisinghe, Jayakody, et al., 2017). Menurut Chapman (1981) pilihan calon taruna/ siswa di perguruan tinggi dipengaruhi oleh serangkaian karakteristik siswa dalam kombinasi dengan serangkaian pengaruh eksternal.

Chapman (1981) menjelaskan bahwa model konseptual secara umum calon mahasiswa yang akan masuk perguruan tinggi didasarkan pada interaksi antara karakteristik taruna/ siswa status sosial ekonomi, bakat, aspirasi dan prestasi pendidikan dan serangkaian pengaruh eksternal. Pengaruh eksternal terbagi dalam tiga kategori (Edirisinghe, Zhihong, et al., 2017) yaitu; orang-orang penting (teman, orang tua, guru sekolah menengah, dan penasihat); karakteristik tetap institusi (biaya, lokasi, ketersediaan program); dan upaya komunikasi perguruan tinggi (kunjungan kampus, informasi tertulis, penerimaan dan kegiatan merekrut).

\section{Pendidikan dan pelatihan vokasi}

Pendidikan dan pelatihan vokasi atau Vocational Education And Training (VET) merupakan program pendiikan dan pelatihan yang dirancang untuk siap kerja, menghadapi tantangan dunia kerja dan mengembangkan teori yang ada dalam pendidikan di perguruang tinggi. VET tidak hanya penting dalam memberikan kesempatan kerja kepada individu tetapi juga membantu dalam meningkatkan produktivitas perusahaan: "Pendidikan dan pelatihan vokasi adalah instrumen yang sangat diperlukan untuk meningkatkan mobilitas tenaga kerja, kemampuan beradaptasi dan produktivitas, sehingga berkontribusi untuk meningkatkan daya saing perusahaan dan memperbaiki ketidakseimbangan pasar tenaga kerja (Agrawal, 2013).

Pentingnya pendidikan dan latihan kejuruan (vokasi) sehingga di berbagai negara mengadakan program yang serupa dengan perbedaan - perbedaan pada tingkat kebijakan pemerintah yang diterapkan. Contoh baik pendidikan dan pelatihan vokasi diterapkan oleh pemerintah finlandia yang sukses dalam pendidikan terbaik di dunia, di Finlandia, pemerintah daerah memainkan peran penting dalam mempromosikan relevansi dan pendekatan berbasis permintaan pendidikan dan pelatihan vokasi. Pemerintah daerah menerapkan pelatihan berkelanjutan yang didanai pemerintah untuk staf pengajar di daerah masing-

Majalah Ilmiah Bahari Jogja 31 | http://jurnal.amy.ac.id/index.php/MIBJ/ 
masing. Selain itu, mereka mengalokasikan hibah untuk keperluan misi lembaga kejuruan untuk mengembangkan dan melayani dunia kerja. Mereka juga mengelola pendanaan ESF regional, yang dialokasikan untuk tujuan seperti pengembangan pembelajaran berbasis kerja (Finnish National Board of Education, 2010). Keterlibatan finlandia dalam pendidikan semua pihak mulai dari akademisi, pemerintah dan dunia kerja (perusahaan) menjadikan finlandia mampu mengelola sumber daya manusia dan sumber daya alam secara maksimal.

Peran kunci dalam pendidikan dan pelatihan vokasi diatur oleh Komite Kualifikasi, yang merupakan badan yang ditunjuk oleh Dewan Pendidikan Nasional Finlandia untuk menerapkan kualifikasi berbasis kompetensi. Komite Kualifikasi bertanggung jawab untuk mengatur dan mengawasi tes kompetensi, memantau efektivitas sistem kualifikasi berbasis kompetensi di bidang VET masing-masing dan, jika perlu, membuat inisiatif mengenai pengembangannya. Komite Kualifikasi menyiapkan kontrak untuk mengatur tes kompetensi untuk kualifikasi yang berbeda dengan penyedia pelatihan yang relevan atau badan lain yang mampu mengatur tes kompetensi untuk kualifikasi terkait sesuai dengan prinsip-prinsip sistem kualifikasi berbasis kompetensi. Mereka memastikan kualitas yang konsisten dari kualifikasi dan sertifikat kualifikasi penghargaan. Finnish National Board of Education (2010) menjelaskan bahwa peran lembaga yang terlibat adalah Parlemen; misalnya membuat undang-undang, Anggaran Negara, kebijakan pendidikan umum. Pemerintah; membuat Dekrit, Rencana pengembangan dan program kebijakan untuk pendidikan dan pelatihan, Tujuan umum studi. Kementerian Pendidikan dan Kebudayaan membuat ; Kebijakan pendidikan khusus, Pengarah, pembiayaan dan regulasi, Kualifikasi. Dewan Pendidikan Nasional Finlandia membuat ; Kurikulum Inti Nasional dan Persyaratan Kualifikasi, Implementasi program pengembangan, Layanan. Komite pendidikan dan pelatihan nasional bekerja dalam bidang; Kontak dengan dunia kerja. Komite kualifikasi menghubungkan kontak dengan dunia kerja. Penyedia VeT memiliki tugas; Perencanaan lokal dan organisasi pendidikan dan pelatihan, Penyediaan pendidikan dan pelatihan, dewan penasihat lokal untuk VET dan badan-badan lainnya, Manajemen kualitas. Administrasi daerah menjalankan tupoksi; Tugas administrasi khusus.

\section{METODE PENELITIAN}

Penelitian menggunakan methode Penelitian Deskriptif kualitatif yaitu metode yang bertujuan untuk membuat deskripsi secara sistematis, faktual, serta akurat pada fakta dan sifat populasi, responden.

Dalam penelitian ini, teknik pengumpulan data yang akan dilakukan peneliti, antara lain:

\section{Angket (Questionnaire)}

Peneliti melakukan teknik pengumpulan data dengan menyerahkan atau mengirimkan daftar pertanyaan untuk diisi oleh para responden, responden dalm hal ini adalah peserta yang mengikuti pendidikan dan latihan. 


\section{Wawancara (Interview)}

Peneliti malakukan teknik pengumpulan data dengan mengajukan pertanyaan langsung oleh pewawancara kepada responden, wawancara dilakukan pada saat pra pelatihan (pendaftaran, rekrutment, pengumpulan syarat administrative) dan pada saat mengikuti pendidikan dan latihan.

\section{Observasi (Observation)}

Observasi dilakukan untuk mendapatkan gambaran real tentang responden yang diteliti. Observasi dilakukan oleh peneliti terhadap responden pada saat proses pelatihan.

\section{Studi Dokumentasi (Documentation Study)}

Peneliti melakukan pengumpulan data yang tidak langsung dengan tujuan menambah pemahaman terhadap subyek dan obyek yang diteliti. Dokumen yang digunakan dapat berupa jurnal - jurnal bereputasi internasional peneltian sebelumnya, melalui web site, dokumen International Marine Organizations (IMO), buku harian, laporan, notulen rapat, catatan-catatan dan dokumen lainnya yang berkaitan dengan pendidikan dan latihan sebelumnya.

\section{Analisis Isi (Content Analysis)}

Peneliti melakukan analisis terhadap data - data yang diperoleh menggunakan deskriptif kualitatif terhadap variabel dan dimensi konsep kebaharuan.

\section{PEMBAHASAN}

Data angket dari sample 280 yang terdiri dari lima angkatan terakhir (2016 - 2020) merujuk pada indikator Prinsip-prinsip EUA Salzburg terdiri atas Keunggulan Penelitian, Lingkungan Kelembagaan yang Menarik, Paparan terhadap industri dan pengusaha terkait lainnya, Jaringan Internasional, Opsi Penelitian Interdisipliner, Pelatihan Keterampilan yang dapat ditransfer, Jaminan Kualitas (Vincx et al., 2018). Menunjukan bahwa dari tahun ke tahun prinsip jaminan kualitas selalu meningkat secara signifikan.

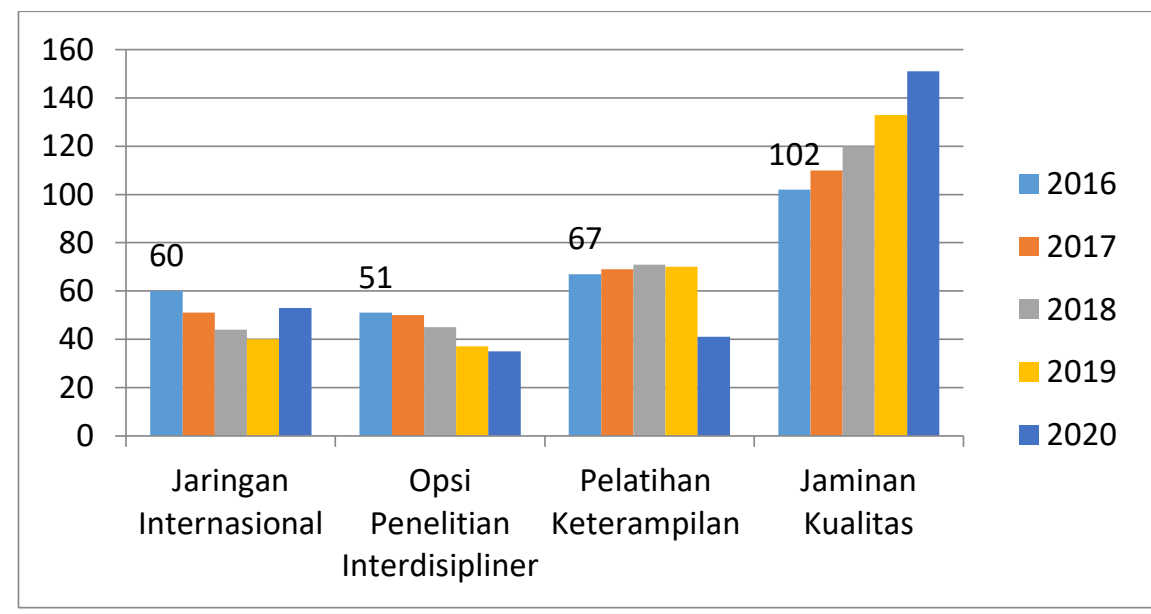

Gambar 1: grafik Prinsip EUA 
Hasil wawancara menunjukan bahwa jaminan kualitas menjadi tujuan mahasiswa mendaftar di perguruan tinggi vokasi dengan berbagai aslasan diantaranya jaminan kualitas yang diberikan oleh pihak pengelola perguruan tinggi vokasi lebih menjanjikan karena siklus hidupnya lebih panjang daripada pelatihan ketrampilan, opsi penelitian interdisipliner atau jaringan internasional yang relatif stagnan, dapat diperoleh diluar tanpa harus kuliah terlebih dahulu.

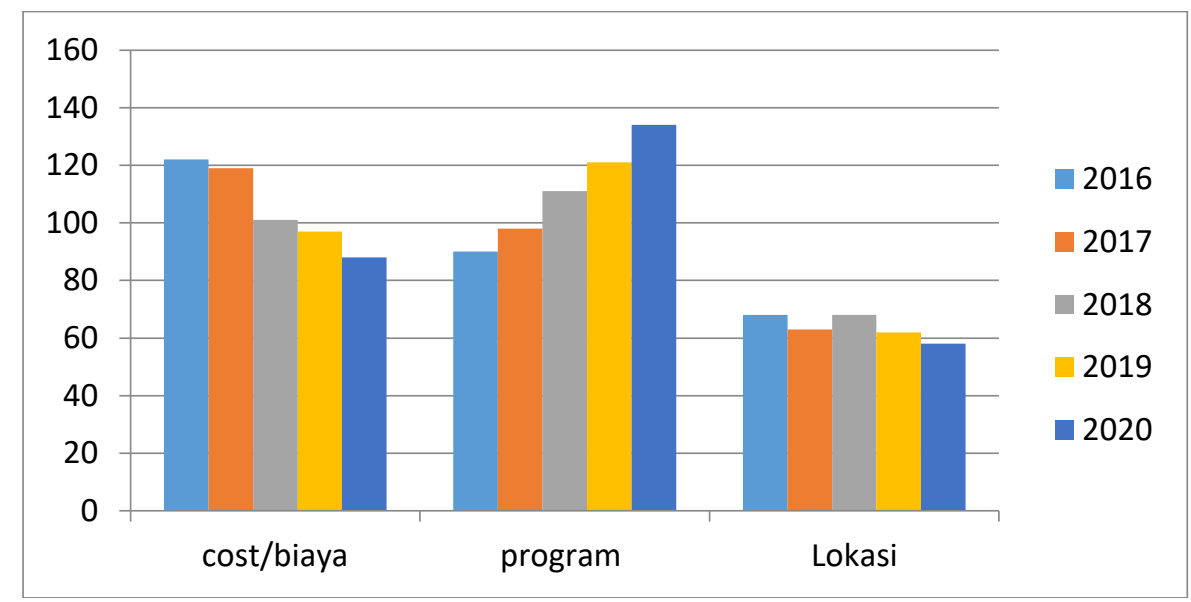

Gambar 2: Grafik kampus pilihan mahasiswa

Chapman (1981) menjelaskan bahwa model konseptual secara umum calon mahasiswa yang akan masuk perguruan tinggi didasarkan pada biaya/ cost, Program yang ditawarkan dan Lokasi perguruan tinggi.

Hasil data dari lima tahun terakhir menyimpulkan bahwa calon mahasiswa program perguruan tinggi yang ditawarkan lebih menarik mahasiswa untuk mendaftar dari pada biaya dan lokasi perguruan tinggi. Biaya pada tahun 2016 menjadi perhatian utam calon mahasiswa, calon mahasiswa yang memiliki keterbatasan biaya tidak akan menjadaftar namun prosentasenya dari tahun ke tahun selalu menurun sampai ke titik terendah pada tahun 2020, hal ini menandakan bahwa biaya sudah tidak lagi menjadi faktor utama calon mahasiswa masuk kuliah, apabila program yang ditawarkan perguruan tinggi bagus maka biaya tidak ada masalah. Sedangkan letak perguruan tinggi itu berada juga tidak menjadi pertimbangan calon mahasiswa itu mendaftar sebab mereka mencara perguruan tinggi yang memiliki program bagus dan kompetitive.

Merujuk pada Finnish National Board of Education (2010) bahwa peran lembaga yang terlibat mengelola pendidikan adalah Parlemen; Pemerintah; Kementerian Pendidikan dan Kebudayaan; Dewan Pendidikan; Komite pendidikan dan pelatihan nasional; Komite kualifikasi dan Penyedia VeT. 


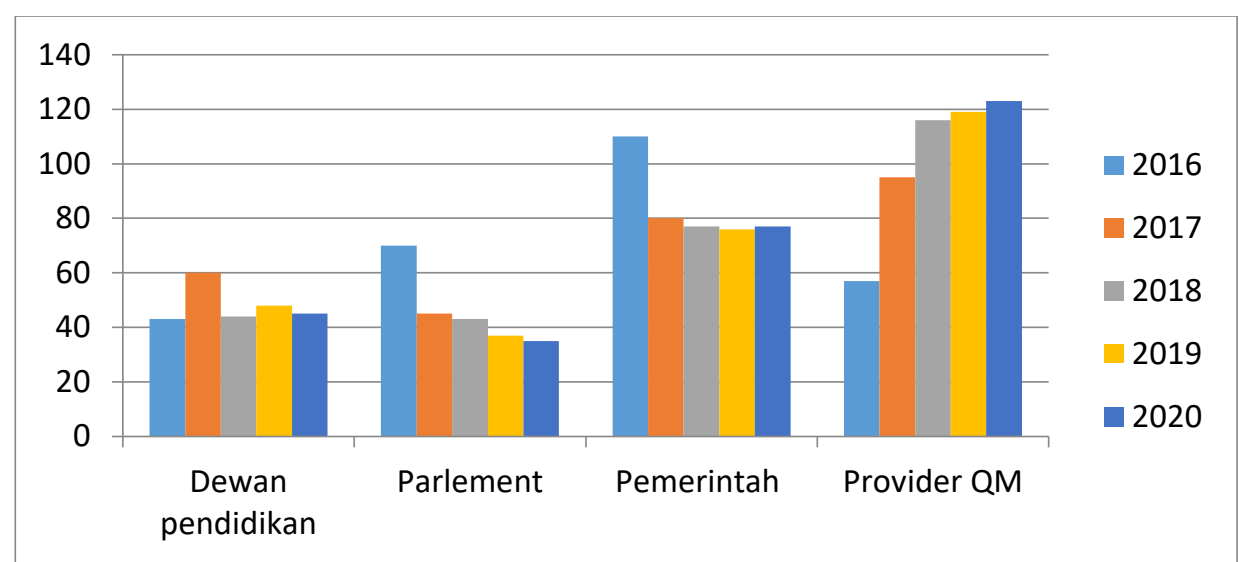

Gambar 3: Grafik Peran Lembaga

Mengelola pendidikan tidak seperti mengelola perusahaan yang hanya mengejar profit namun harus dikelola dengan profesional, tanggung jawab dan ada tanggung jawab mencerdaskan kehidupan bangsa. Semua komponen lembaga Negara harus terlibat untuk memajukan pendidikan mulai dari dewan pendidikan, parlemen/DPR, Pemerintah dan penyedia pendidikan Vokasi terutama kualitas manajemen.

Penyedia pendidikan vokasi berperan besar untuk mampu meningkatkan sumber daya yang memiliki skill tinggi dan kualitas menejemen yang baik. peran dewan pendidikan dari tahun ke tahun meningkat seiring kesadaran masyarakat akan pendidikan untuk menaikan kualitasnya, peran parlemen/ DPR masih diperlukan untuk membuat undang - undang dan melindungi badan pendidikan namun perannya dari tahun 2016 hingga 2020 berkurang, peran pemerintah sangat diperlukan untuk meningkatkan pendidikan vokasi.

Hasil penelitian menunjukan bahwa masyarakat sebagian besar menghendaki pendidikan (formal dan informal) harus memiliki program dengan jaminan kualitas pendidikan tersebut mengalami siklus hidup yang selalu dapat diperbaharui dan hal tersebut akan bisa dilakukan apabila ada kualitas manajemen baik. Maka, Quality Program Life Cycle perlu diterapkan pada pendidikan formal dan informal untuk memperoleh kualitas sumber daya manusia unggul. Secara sederhana integarasi teoritis konsep model Quality Program Life Cycle dapat digambarpak pada gambar 4. 

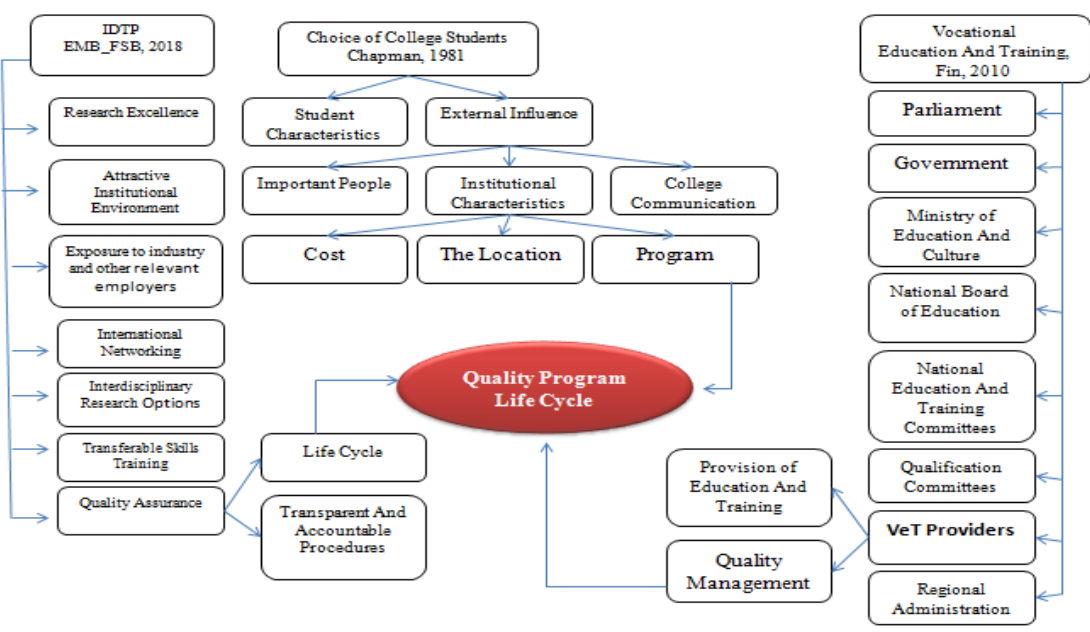

Gambar 4: Integrasi Konsep Quality Program Life Cycle

Quality Program Life Cycle adalah model pendidikan vokasi yang mengutamakan kualitas (perekrutan, pendidikan, pelatihan dan pendampingan) secara berkualitas (taruna, dosen, karyawan/staff, peserta pelatihan) dengan program yang terukur, tansparan dan akuntabilitas dengan keterlibatan penuh institusi/lembaga, mahasiswa dan perusahaan sebagai perputaran (Life Cycle) secara berkelanjutan. Program pendidikan/ pelatihan yang berkualitas terus diperbaharui dengan melakukan koreksi berkelanjutan. Grand desain Quality Program Life Cycle digambarkan sebagai berikut;

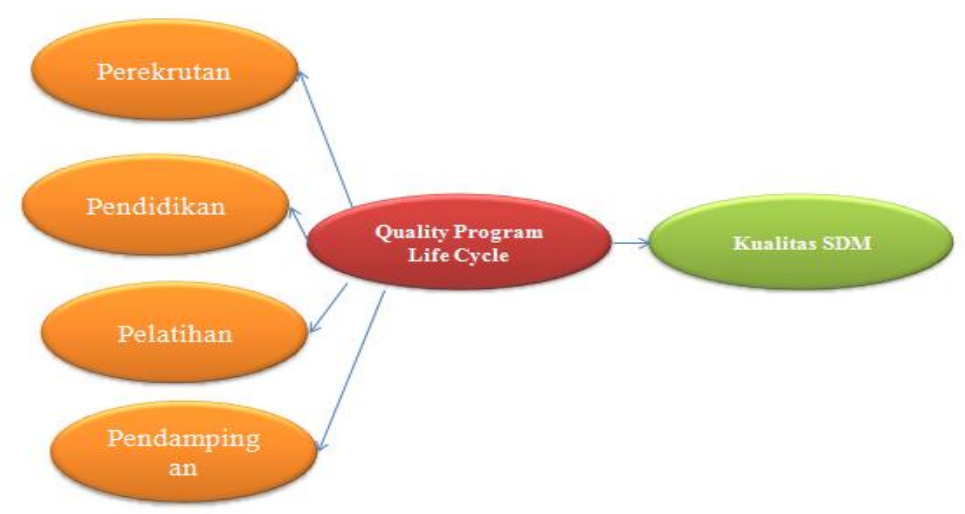

Gambar 5: Konsep Model Quality Program Life Cycle

Quality Program Life Cycle dimuali dari proses perekrutan calon mahasiswa/ calon peserta pelatihan/ shortcut secara transparan memenuhu syarat syarat yang telah ditentukan sebelumya, hal ini sangat penting dilakukan sebab proses perekrutan merupakan penentu untuk tahap selanjutnya. Kedua setelah perekrutan adalah mengikuti pendidikan. Pendidikan yang dimaksud adalah proses calon taruna/ peserta pelatihan mengikuti dari awal hingga akhir pembelajaran yang dilakukan baik di dalam ruangan maupun di luar ruangan dengan serius sedangkan pelatihan adalah proses yang dilakukan secara praktek baik di dalam ruangan atau di luar ruangan, mengaplikasikan teori dalam proses 
pendidikan kedalam praktek di lapangan secara benar. Tahap akhir adalah pendampingan. Pada tahap ini seluruh tahapan mulai dari perekrutan hingga pelatihan dievaluasi kelebihan dan kelemahanya baik dari program maupun lembaga yang terlibat serta sumber daya manusia baik peserta maupun penyelenggara, apabila ada kelemahan dalam rangkaian proses tersebut maka segera diperbaiki (Life Cycle).

\section{PENUTUP}

\section{Kesimpulan dan Saran}

Masyarakat menghendaki program pendidikan dan pelatihan yang berkualitas dan dikelola oleh manajemen yang berkualitas. Hasil penelitian menunjukan bahwa pendidikan dan pelatihan yang baik tidak mempermasalahkan berapa biaya pendidikan, seberapa jauh jarak yang harus ditempuh antara tempat diadakan proses pendidikan dan pelatihan antara penyelenggara pendidikan dengan calon mahasiswa/ peserta pendidikan dan pelatihan. Kualitas pendidikan yang buruk hanya akan menghasilkan pengannguran terdidik karena tidak sesuai dengan dunia kerja (Medina and Suthers, 2008; International Labour Organization ILO, 2020). Sebagian besar hasil penelitian juga menunjukan bahwa mereka lebih mementingan kualitas program pendidikan dan pelatihan yang ditawarkan oleh penyelenggara secara nyata sebab selama ini hanya program yang baik namun tidak pernah dilaksanakan, pelaksanaan kualita pendidikan harus didukung oleh semua stakeholder. Program kualitas pendidikan formal dan informal harus terus ditingkatkan dan diperbaiki secara berkelanjutan untuk meningkatkan kualitas sumber daya manusia unggul. Salah satu untuk mendapatkan sumber daya manusia unggul adalah dengan Quality Program Life Cycle.

Program pendidikan dan pelatihan Quality Program Life Cycle berkualitas harus didukung oleh semua pihak sehingga, dewan perwakilan rakyat sebagai pembuat kebijakan, pemerintah sebagai pengendali kebijakan Kementerian Pendidikan dan Kebudayaan; Dewan Pendidikan; Komite pendidikan dan pelatihan nasional; Komite kualifikasi dan Penyedia Program Vokasi baik pendidikan maupun pelatihan.

\section{DAFTAR PUSTAKA}

Adhuri, D. S. (2018). The State and Empowerment of Indonesian Maritime Culture: The Case of Traditional Marine Resource Management. Journal of Ocean \& Culture. https://doi.org/10.33522/joc.2018.1.18

Adi, T. R. (2018). Maritime Culture Empowerment under Indonesian Ocean Policy. Journal of Ocean \& Culture, 1, 102-117. https://doi.org/10.33522/joc.2018.1.102

Agrawal, T. (2013). Vocational education and training programs (VET): An Asian perspective. Asia-Pacific Journal of Cooperative Education, 14(1), 15-26.

Alihar, F. (2018). KEBIJAKAN PENGELOLAAN PULAU-PULAU TERLUAR Policies on The Management of The Outer Islands According. 39-51.

Astriawati, N., \& Wibowo, W. (2019). Peningkatan Motivasi Dan Hasil Belajar 
Taruna Melalui Media Berbasis "Whiteboard Animation" Bidang Navigasi Pelayaran. Prosiding Konferensi Nasional Penelitian Dan Pembelajarannya IV, $\quad$ p-28. Retrieved from https://publikasiilmiah.ums.ac.id/handle/11617/11047

Badan Pusat Statistik. (2019). Jumlah Pulau di Indonesia Berkurang Menjadi 16 Ribu. Databoks, 2018.

Binat Sarwar, M., \& Hunt, A. (2017). Study: Women's Economic Empowerment at International Level. European Union. https://doi.org/10.2861/903280

Chapman, D. W. (1981). A Model of Student College Choice. The Journal of Higher Education, 52(5), 490. https://doi.org/10.2307/1981837

Defence, the M. of R. I. (2015). Defence Ministry of the Republic of Indonesia (W H I T E). Indonesia: Ministry of defence of the republic of Indonesia.

Edirisinghe, L., Jayakody, N., Ranwala, L., \& Lixin, S. (2017). Factors That Determines the Students' Choice of Maritime Education and Training with Special Reference to Seafaring Officers. SSRN Electronic Journal, (March 2017). https://doi.org/10.2139/ssrn.2966631

Edirisinghe, L., Zhihong, J., \& Lixin, S. (2017). The Direction of Maritime Education and Training Development: A Conceptual Approach. SSRN Electronic Journal, (March). https://doi.org/10.2139/ssrn.2966605

EUA. (2005). Report: Salzburg Principles (Doctoral Programmes for the European Knowledge Society) (EUA). (February 2005), 3-5.

Finnish National Board of Education. (2010). Vocational education and training in Finland. 1-28.

Francis, J., Celliers, L., \& Rosendo, S. (2015). Coastal and Marine Research and Capacity Building. (JUNE). https://doi.org/10.13140/RG.2.1.3100.0805

Herdiana. (2013). 済無No Title No Title. Journal of Chemical Information and Modeling, 53(9), 1689-1699. https://doi.org/10.1017/CBO9781107415324.004

International Labour Organization ILO. (2020). Global Employment Trends for Youth 2020: Technology and the future of jobs.

Juwana, H. (2003). Putusan MI Atas Pulau Sipadan Dan Ligitan. Indonesian Journal of International Law, 1(1), 169-182.

Kristianto, L., \& Astriawati, N. (2019). Pengaruh Blended Learning Berbasis Edmodo Pada Mata Kuliah Teknologi Informatika I. (September), 314-320.

Labas, I., Darabos, E., \& Nagy, T. O. (2018). Competitiveness - higher education. Studia Universitatis ,, Vasile Goldis” Arad-Economics Series, 26(1), 11-25. https://doi.org/10.1515/sues-2016-0002

Mechael, P. N. (2007). Creating an enabling environment for mHealth. 2007 ITI 5th International Conference on Information and Communications Technology, ICICT 2007, 251-255. https://doi.org/10.1109/ITICT.2007.4475657

Medina, R., \& Suthers, D. D. (2008). Bringing representational practice from log to light. In Computer-Supported Collaborative Learning Conference, CSCL.

Morton, M., \& Montgomery, P. (2010). PROTOCOL: Youth empowerment programs for improving self-efficacy and self-esteem of adolescents. Campbell Systematic Reviews, 6(1), 1-38. https://doi.org/10.1002/cl2.71 
Nugraha, M. H. R. (2018). Jurnal Pertahanan. Jurnal Pertahanan, 4(1), 61-75.

Ohlsson, H., \& Borg, H. (2010). Career development. Career Development, (2018), 1-183. https://doi.org/10.4324/9781351048941-4

Pilz, M. (2012). The Future of Vocational Education and Training in a Changing World. The Future of Vocational Education and Training in a Changing World, (January 2012), 1-592. https://doi.org/10.1007/978-3-531-18757-0

Sabic, N., \& Kemmerling, A. (2011). Comparative analysis of doctoral education in Political Science and Related Fields. (November), 4-5.

Shury, J., Vivian, D., \& Turner, C. (2017). Planning for success: Graduates' career planning and its effect on graduate outcomes. (March).

Soedarto, T. (2017). The 1 st International Joint Conference on Science and Technology ( IJCST ). (October).

Stankevich, A. (2017). Explaining the Consumer Decision-Making Process: Critical Literature Review. Journal of International Business Research and Marketing, 2(6), 7-14. https://doi.org/10.18775/jibrm.18498558.2015.26.3001

Vincx, M., Antia, A., Deprez, T., Fiksen, O., Koski, M., MacKenzie, B., ... Roullet, G. (2018). Training the 21st Century Marine Professional. EMB Future Science Brief 2, (April).

Wahid, A., Ahmad, M. S., Abu Talib, N. B., Shah, I. A., Tahir, M., Jan, F. A., \& Saleem, M. Q. (2017). Barriers to empowerment: Assessment of communityled local development organizations in Pakistan. Renewable and Sustainable Energy Reviews, 74(February 2018), 1361-1370. https://doi.org/10.1016/j.rser.2016.11.163 